\title{
Review
}

\section{Before the Law: The complete text of Préjugés}

\author{
Jacques Derrida \\ Sandra van Reenen and Jacques de Ville (Trans.) \\ University of Minnesota Press, Minneapolis and London, 2018, ix + 78 pp., \\ ISBN: 978-1-5179-0551-4
}

Contemporary Political Theory (2020) 19, S145-S148. https://doi.org/10.1057/s41296019-00315-1; published online 19 March 2019

Jacques Derrida has always divided critical opinion, generally very sharply, and the texts that have been coming out in English translation since his death have continued that process. Before the Law is the latest, a two-part text that was delivered at a conference on the work of Jean-François Lyotard, in particular his writings on the subject of judgement. Hence the question with which Derrida opens the proceedings: 'How to judge - Jean-François Lyotard?' (p. 3). The first part consists of a series of meditations on the nature of judgement, exploring what it means to us and how we relate to the law, using Lyotard as a point of reference, while in the second part Derrida considers what implications Franz Kafka's short story Before the Law holds for the act of judgement. Some readers may already have come across the Kafka material in Acts of Literature (1992), an edited collection of Derrida's works. Before that, it was the subject of a lecture he gave at the Royal Philosophical Society in London in the early 1980s. The Kafka narrative is a typically opaque tale about judgement and choice, where a man is repeatedly barred admission to 'the Law' over the course of his lifetime by a doorkeeper (although also dared by the latter to disregard his refusal to enter), only to be told at the end that 'this gate was made only for you. I am now going to shut it' (p. 25). It fits Derrida's purposes well here, leaving us in doubt as to whether we can ever justify making judgements, and perhaps more worryingly, whether 'the Law' ever can.

All of Derrida's familiar techniques are on display in this work: the circuitous approach to the topic under discussion; the strings of questions that spin off from each other and are invariably left hanging; the postponement of conclusions; the sudden change of topic, tone and register; the somewhat anarchic overall line of argument. It is a style which bears little resemblance to standard philosophical discourse in the English-speaking world and has a tendency to cloud rather than clarify the issues at hand. We are no wiser by the end of Before the Law on how to

(c) 2019 Springer Nature Limited. 1470-8914 Contemporary Political Theory Vol. 19, S2, S145-S148 
go about judging Lyotard, or how Derrida himself judges the work of his compatriot - except that it is very hard to do that about anyone. Instead, we are treated to a disquisition on what it means to judge, or more correctly, how we can never quite get to the point of judging, or to be able to justify the act of judging itself. It is Derrida at his most digressive, and to non-deconstructionists it will no doubt be a frustrating exercise to engage with this book, particularly when we are told in its closing pages that, '[t]his has been the scene for a reading that was only minimally categorical. I have risked glosses, have given multiple interpretations, asked and avoided answering questions, abandoned decoding before it was complete, and left enigmas intact, beginning with Jean-François Lyotard' (p. 71). One might wonder what the point of the exercise was then. What we always have to remember with Derrida is that style is content. Before the Law is a practical illustration of how deconstruction works within language, of how meaning keeps slipping away as a text unfolds. 'How to judge - Jean-François Lyotard?', may be Derrida's starting point, therefore, but he is soon going off at a tangent: 'Given that the question has been asked, and quoted, and given that the person it concerns has already been quoted, "How to judge - Jean-François Lyotard?", do I have the right to turn this question into another one: "Who is Jean-François Lyotard?" Would I, by answering one of these questions, have answered the other?' (p. 5). This is a very typical Derrida move - The Truth in Painting (1987) is full of them - and as a method it can be irritating in that it represents a digression from the topic at hand, one that risks losing the reader expecting a more straightforward line of argument.

Derrida samples Lyotard's work on judgement (mainly from the set of interviews with Jean-Loup Thébaud in Just Gaming (1985)), but without ever analysing it in any detail. In Just Gaming, Lyotard faces up to the main problem faced by sceptically oriented thinkers: how to make value judgements if truth is a relative, rather than an absolute concept. Conceding that he can present no criteria for doing so (except for the criterion of having no criteria, as he somewhat glibly asserts), Lyotard then goes on to suggest ways around the predicament, such as 'case by case' judgements in the style of Aristotle, whereby decisions are made after an unbiased examination of the particulars involved in the given situation. The critical point, however, is that these decisions cannot be taken as precedents in future cases: each assessment of a case has to start from scratch. What Derrida seems concerned to show, on the other hand, is how we could never actually reach the point of feeling able to make a decision. In many ways, Derrida is the sceptic's sceptic. Just as the classical sceptic Sextus Empiricus argued, in Outlines of Scepticism (1994), that because there was never an ultimate ground of truth it was better to opt out of the exercise of trying to locate it and instead cease having any beliefs at all, Derrida demonstrates our lack of justification for ever attempting judgement in the first place. Behind every question like 'How to judge-JeanFrançois Lyotard?' lies a preliminary question along the lines of 'Who is JeanFrançois Lyotard?' - and so on, indefinitely. Questions in Derrida's work 
inevitably raise other questions rather than answers, moving us further and further away from the original concern. This is a quite deliberate tactic on Derrida's part, as he openly admits: 'At bottom, the whole discourse on différance, on undecidability, etc., can also be considered as a means of keeping one's distance from judgement in all its forms (predicative, prescriptive; always decisive)' (p. 17).

Even if it is all too easy to be critical of Derrida's style, there is nevertheless something there that demands to be taken seriously, and that, paradoxically enough perhaps, justifies the deconstructive enterprise. Derrida brings out the arbitrary quality of so many of our systems (such as, in this instance, law), inviting us to recognise just how many assumptions are built into them, assumptions that cannot really be substantiated. Once you move out of a religious framework and Godgiven laws and commandments, then law is a matter of convention and tradition ('legal fictions', as the text's prefatory Montaigne quote puts it), and the question of how to judge, of what it means to judge, becomes problematic. The more you think about it, the more problematic it becomes; there are criteria, but what lies behind these criteria? The games Derrida plays with the notion of judging indicate just how lacking in substance the act of value judgement can be, and just how much we take for granted about the vexed issue of justification: 'In its very form, the question "How to judge?" seems at least to prejudge [prejuger] what it means to judge. The situation is that, since we know, or we presuppose what it means to judge, we ask ourselves only how should we judge?' (p. 13). He may go about this task in a roundabout way, but it cannot be denied that Derrida forces us to think about a topic that has implications going well beyond philosophy. How much prejudice goes into our judgements, and can we ever avoid this from happening? Reflecting on that at any length can be very uncomfortable. But, and it is a big 'but', in the real world, as opposed to the conference hall, we still have to make value judgements - about dramatic phenomena like murder, or genocide, for example. For all the barriers that relativism puts in his way, Lyotard never loses sight of that fact, striving to find ways to distinguish between just and unjust acts, recognising that it is neither possible, nor desirable, to keep one's distance from judgement. That is not, however, a Lyotard that we encounter much in this book.

\section{References}

Derrida, J. (1987) The Truth in Painting, trans. G. Bennington and I. McLeod. Chicago and London: University of Chicago Press.

Derrida, J. (1992) In D. Attridge, Acts of Literature. New York: Routledge.

Lyotard, J.-F. and Thébaud, J.-L. (1985) Just Gaming, trans. W. Godzich. Manchester: Manchester University Press.

Sextus Empiricus. (1994) Outlines of Scepticism, trans. J. Annas and J. Barnes. Cambridge: Cambridge University Press.

(c) 2019 Springer Nature Limited. 1470-8914 Contemporary Political Theory Vol. 19, S2, S145-S148 S147 
Publisher's Note Springer Nature remains neutral with regard to jurisdictional claims in published maps and institutional affiliations.

Stuart Sim

Northumbria University, Newcastle-upon-Tyne NE1 8ST, UK stuartsim2@aol.com 